\title{
Different Resistance Mechanisms of Medicago truncatula Ecotypes Against the Rust Fungus Uromyces striatus
}

\author{
Eric Kemen, Matthias Hahn, Kurt Mendgen, and Christine Struck
}

First, third, and fourth authors: University of Konstanz, Department of Biology, Phytopathology, Universitätsstr. 10, 78457 Konstanz, Germany; and second author: University of Kaiserslautern, Department of Biology, P.O. Box 3049, 67653 Kaiserslautern, Germany.

Current address of C. Struck: University of Rostock, Faculty of Agricultural and Environmental Sciences, Institute for Land Use, Crop Health, Satower Str. 48, 18051 Rostock, Germany.

Accepted for publication 16 September 2004.

\begin{abstract}
Kemen, E., Hahn, M., Mendgen, K., and Struck, C. 2005. Different resistance mechanisms of Medicago truncatula ecotypes against the rust fungus Uromyces striatus. Phytopathology 95:153-157.

A pathosystem consisting of the model plant Medicago truncatula and the rust fungus Uromyces striatus was characterized. From a collection of

infect. After penetration, the resistant ecotypes reacted with various degrees of cell death during different stages of haustorial establishment. Whereas four ecotypes showed a typical hypersensitive reaction by developing necrotic lesions, one ecotype (F11.008) exhibited a prehaustorial type of defense without hypersensitive response. This ecotype may be used as a source of nonhost-type of resistance against $U$. striatus.
\end{abstract} 113 mostly European accessions of $M$. truncatula, the vast majority were found to be susceptible to $U$. striatus, whereas 5 accessions showed strong resistance reactions. Stomatal surface characteristics, even if partly occluded, did not interfere with the ability of $U$. striatus germ tubes to
Additional keywords: alfalfa, appressorium formation, autofluorescence, haustorium, nonhost resistance.
The annual legume Medicago truncatula Gaertn. is a member of the phylogenetic "galegoid" group, which comprises agronomically significant crop species such as pea (Pisum sativum), broad bean (Vicia faba), chickpea (Cicer arietinum), and alfalfa (Medicago sativa) (21). Due to the relatively small, diploid genome $(\approx 500 \mathrm{Mbp})$ and a short generation time, M. truncatula has been established as a model plant for molecular and genetic studies with the aim to identify agronomically important genes in other legumes.

Searching for new sources of resistance in crop plants to important pathogens has been done by screening host plants or closely related plants $(1,17)$, including $M$. truncatula (14). Resistant cultivars provide the resources for further analysis of the molecular mechanisms underlying genetic diversity for plant pathogen resistance. The alfalfa rust Uromyces striatus J. Schröt. is widely distributed in four of the five continents $(6,7)$. The worldwide dispersal of this fungus could be the result of the broad host range which comprises at least 141 species and subspecies from the tribes Trifolieae, Cicereae, and Vicieae, including alfalfa ( $M$. sativa) and barrel medic (M. truncatula) (15). Therefore, resistance reactions of the "nonhost" type appear unusual and should be used as a promising resource for molecular analysis and breeding for resistance.

In this article, we have studied Mediterranean and some Australian accessions of $M$. truncatula. We show that stomatal structures do not contribute to unspecific resistance, but we describe one example where haustorial mother cells cannot penetrate healthy host cells.

Corresponding author: C. Struck; E-mail address: Christine.Struck@uni-rostock.de

\section{DOI: 10.1094/PHYTO-95-0153}

This article is in the public domain and not copyrightable. It may be freely reprinted with customary crediting of the source. The American Phytopathological Society, 2005.

\section{MATERIALS AND METHODS}

Plant material, growth conditions, and inoculation procedure. Five $U$. striatus single-spore isolates were obtained from different host plants and habitats. Because they showed no differences in their infection rates on $M$. sativa and M. truncatula, the isolate $\mathrm{KN} 1$, which was obtained from naturally grown $M$. sativa on the campus of the University of Konstanz (Germany), was selected for further studies. For the experiments, only uredospores were used.

Seed of 113 cultivars and lines selected from natural populations of M. truncatula and $M$. sativa cv. Europe (KWS, Einbeck, Germany) distributed throughout the Mediterranean basin (kindly supplied by J. M. Prosperi, INRA, Montpellier, France) were grown under controlled conditions $\left(22^{\circ} \mathrm{C}, 16 \mathrm{~h}\right.$ of light; $20^{\circ} \mathrm{C}, 8 \mathrm{~h}$ of darkness, $70 \%$ relative humidity). Five to seven 3-week-old plants were inoculated by spraying with $10 \mathrm{mg}$ of uredospores suspended in $1 \mathrm{ml}$ of kerosene using an air brush. Plants were allowed to dry for $30 \mathrm{~min}$. In order to get open stomata, M. truncatula plants were exposed to light for $1 \mathrm{~h}$. All plants were incubated in darkness for $24 \mathrm{~h}$ at $20^{\circ} \mathrm{C}$ and $100 \%$ relative humidity.

Screening for resistance. Two weeks after inoculation, plants were screened for resistance to $U$. striatus. Symptoms were classified according to Stakman et al. (16). The scale was expanded for better resolution of the infection types. Class 0 (some chlorosis without visible pustules) and class 1 (very small pinpoint pustules surrounded by necrosis) were regarded as resistant. Class 2 described an intermediate interaction type (few small pustules with extensive chlorosis). Classes 3 and 4 were regarded as susceptible (pustules with chlorosis and large pustules with little or no chlorosis, respectively). To confirm the results, plants of compatibility classes 0,1 , and 2 were inoculated again and tested 3 and 4 weeks after inoculation.

Low-temperature scanning electron microscopy. Segments of leaf tissue $\left(25 \mathrm{~mm}^{2}\right)$ were mounted on sample holders with Tis- 
sue-tek (Sakura, Tokyo) and plunge-frozen in nitrogen slush. By using a vacuum transfer device, samples were transferred into the Alto 2500 (Gatan, Oxford, UK) vacuum preparation chamber (pressure $<2 \times 10^{-4} \mathrm{~Pa}$ ) and mounted onto the cryostage precooled to $93 \mathrm{~K}$. For sublimation of ice on the sample surface, the cryostage temperature was raised to $176 \mathrm{~K}$ for $30 \mathrm{~s}$ and then cooled to $143 \mathrm{~K}$. Samples were sputter coated with a 5-nm-thick platinum layer and afterwards transferred to the scanning electron microscopy (SEM) cryostage cooled to $148 \mathrm{~K}$. Examination was performed with a S-4700 field emission scanning electron microscope (Hitachi, Tokyo) at an acceleration voltage of $2 \mathrm{kV}$. SEM micrographs were recorded digitally in a 40-s scanning mode.
Histology. For studying the fungal development on leaf surfaces, inoculated plant material was collected 1 day after inoculation, fixed with $0.2 \%$ glutaraldehyde, and afterwards stained and mounted according to Vaz Patto and Niks (20).

In order to follow the fungal growth within the tissue, and to determine the extent of host cell defense responses (cell death and autofluorescence), leaves were harvested daily until the fifth day as well as 7, 9, and 14 days after inoculation. Samples were fixed in acetic acid:ethanol $(1: 3, \mathrm{vol} / \mathrm{vol})$, cleared with preheated $\left(95^{\circ} \mathrm{C}\right)$ lactophenol:ethanol $(1: 2, \mathrm{vol} / \mathrm{vol})$, and stained in $0.1 \%$ trypan blue. After incubation in boiling $0.125 \mathrm{M} \mathrm{KOH}$ for 1 to $3 \mathrm{~min}$, samples were mounted in $100 \%$ glycerol. Images were obtained

TABLE 1. Evaluation of Medicago truncatula accessions for resistance to Uromyces striatus

\begin{tabular}{|c|c|c|c|c|c|}
\hline Accession & Origin & Compatibility class $^{\mathrm{a}}$ & Accession & Origin & Compatibility class $^{\mathrm{a}}$ \\
\hline Ampus & France & 3 & ESP.100 & Spain & 1 \\
\hline Borung & Australia & 3 & ESP.101 & Spain & 3 \\
\hline Caliph & Australia & 4 & ESP.103 & Spain & 3 \\
\hline Cyprus & Australia & 4 & ESP.104 & Spain & 4 \\
\hline Jemalong A17 & $\ldots$ & 4 & ESP.105 & Spain & 3 \\
\hline Paraggio & Australia & 4 & ESP.140 & Spain & 3 \\
\hline Sephi & Australia & 3 & ESP.155 & Spain & 4 \\
\hline 012.102 & Switzerland & 3 & ESP.156 & Spain & 4 \\
\hline CRE.005 & Crete & 4 & ESP. 158 & Spain & 3 \\
\hline CRE.006 & Crete & 3 & ESP.159 & Spain & 4 \\
\hline CRE.007 & Crete & 3 & ESP.160 & Spain & 3 \\
\hline CRE.009 & Crete & 4 & ESP.161 & Spain & 4 \\
\hline DZA.012 & Algeria & 3 & ESP.162 & Spain & 1 \\
\hline DZA.016 & Algeria & 4 & ESP.163 & Spain & 4 \\
\hline DZA.022 & Algeria & 3 & ESP. 165 & Spain & 4 \\
\hline DZA.027 & Algeria & 2 & ESP.169 & Spain & 4 \\
\hline DZA.033 & Algeria & 3 & ESP.170 & Spain & 4 \\
\hline DZA.045 & Algeria & 1 & ESP.172 & Spain & 3 \\
\hline DZA.046 & Algeria & 3 & ESP.173 & Spain & 3 \\
\hline DZA.055 & Algeria & 3 & ESP.174 & Spain & 4 \\
\hline DZA.058 & Algeria & 3 & ESP. 175 & Spain & 3 \\
\hline DZA.059 & Algeria & 4 & F11.005 & France & 3 \\
\hline DZA.061 & Algeria & 3 & F11.007 & France & 3 \\
\hline DZA.105 & Algeria & 4 & F11.008 & France & 0 \\
\hline DZA.202 & Algeria & 4 & F11.012 & France & 3 \\
\hline DZA.210 & Algeria & 4 & F11.013 & France & 3 \\
\hline DZA.213 & Algeria & 4 & F20.009 & France & 3 \\
\hline DZA. 219 & Algeria & 3 & F20.015 & France & 4 \\
\hline DZA.220 & Algeria & 3 & F20.025 & France & 3 \\
\hline DZA.221 & Algeria & 4 & F20.031 & France & 3 \\
\hline DZA.222 & Algeria & 3 & F20.047 & France & 3 \\
\hline DZA. 230 & Algeria & 4 & F20.048 & France & 3 \\
\hline DZA. 231 & Algeria & 4 & F20.058 & France & 3 \\
\hline DZA.233 & Algeria & 4 & F20.061 & France & 4 \\
\hline DZA.236 & Algeria & 4 & F20.069 & France & 4 \\
\hline DZA.241 & Algeria & 3 & F20.081 & France & 3 \\
\hline DZA.242 & Algeria & 4 & F20.086 & France & 4 \\
\hline DZA.243 & Algeria & 3 & F20.087 & France & 3 \\
\hline DZA.244 & Algeria & 3 & F20.089 & France & 3 \\
\hline DZA.246 & Algeria & 4 & F34.042 & France & 3 \\
\hline DZA. 248 & Algeria & 3 & GRC.020 & Greece & 4 \\
\hline DZA.312 & Algeria & 4 & GRC.033 & Greece & 4 \\
\hline DZA.323 & Algeria & 3 & GRC.037 & Greece & 4 \\
\hline DZA. 327 & Algeria & 4 & GRC. 040 & Greece & 4 \\
\hline ESP.031 & Spain & 4 & GRC.043 & Greece & 4 \\
\hline ESP.039 & Spain & 4 & GRC.052 & Greece & 4 \\
\hline ESP.040 & Spain & 3 & GRC.063 & Greece & 3 \\
\hline ESP.041 & Spain & 4 & GRC.064 & Greece & 4 \\
\hline ESP.043 & Spain & 4 & GRC.065 & Greece & 4 \\
\hline ESP.045 & Spain & 3 & GRC.093 & Greece & 3 \\
\hline ESP.048 & Spain & 4 & GRC.098 & Greece & 1 \\
\hline ESP.074 & Spain & 4 & PRT.176 & Portugal & 4 \\
\hline ESP.080 & Spain & 3 & PRT.177 & Portugal & 4 \\
\hline ESP.095 & Spain & 3 & PRT.178 & Portugal & 4 \\
\hline ESP.096 & Spain & 4 & PRT.179 & Portugal & 3 \\
\hline ESP.098B & Spain & 4 & PRT.180 & Portugal & 3 \\
\hline ESP.099A & Spain & 4 & & & \\
\hline
\end{tabular}

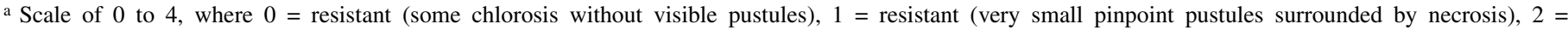
intermediate (few small pustules with extensive chlorosis), $3=$ susceptible (pustules with chlorosis), and $4=$ susceptible (large pustules with little or no chlorosis). 
using an epifluorescence microscope (Axioplan, Carl Zeiss Jena $\mathrm{GmbH}$, Germany) equipped with Zeiss filter set 05 (excitation BP 395-440, beamsplitter FT 460, emission LP 470), Zeiss objectives (Plan-Neofluar 40×/1,3 Oil, Plan-Neofluar 25×/0,80 imm. Korr.) and a CCD camera (AxioCam, Carl Zeiss Vision $\mathrm{GmbH}$, Germany).

For quantitative determination of haustorium formation and of host cell death responses, each experiment was performed at least twice with at least three leaves and 30 infection sites per leaf.

\section{RESULTS}

Screening of $M$. truncatula accessions. In order to study genetic variation in $M$. truncatula for the response to rust infection, we screened 113 different accessions, including 7 cultivars and 106 ecotypes from seven different countries and regions, for resistance against $U$. striatus race $\mathrm{KN} 1$. Symptoms were classified as listed in Table 1. Most M. truncatula accessions (108) exhibited highly susceptible or intermediate interactions, whereas 5 showed strong resistance reactions (interaction type 0 or 1 ). The five resistant ecotypes (DZA.045, ESP.100, ESP.162, F11.008, and GRC.098) were selected for further investigation. Their interaction types with $U$. striatus were compared with that of the susceptible $M$. truncatula cv. Jemalong and that of the original host plant $M$. sativa $\mathrm{cv}$. Europe during the first days of infection on a cytological level.

Topography sensing. An important factor in achieving successful penetration of a host plant surface is the ability of the dikaryotic rust germ tube to recognize stomatal openings. Microscopic analysis $24 \mathrm{~h}$ after inoculation revealed that germination on the leaf epidermis and formation of appressoria over stomata did not differ statistically between the two susceptible Medicago cultivars and the resistant $M$. truncatula lines (data not shown), an observation already described by Rubiales and Moral (14) for Australian accessions. SEM data revealed major differences in leaf surface structures surrounding the stomata of the investigated Medicago lines. Accessions differed in number of wax crystals
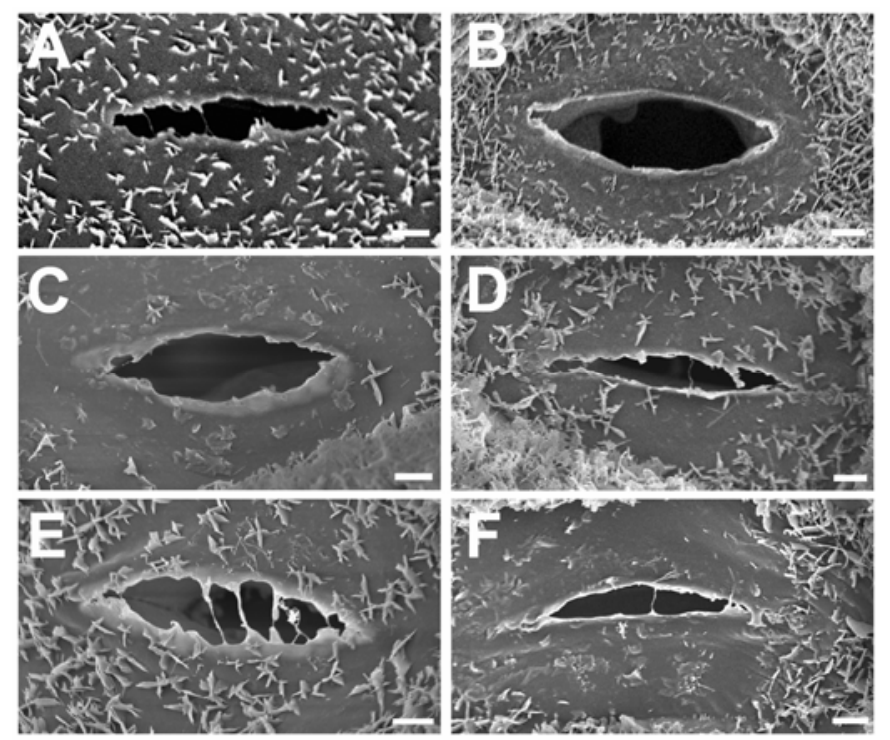

Fig. 1. Surface topography of stomata of various Medicago truncatula accessions and of $M$. sativa. A, In $M$. sativa cv. Europe, stomatal ledges are dentated and the guard cells are covered with epicuticular wax crystals. B, In M. truncatula Jemalong A17, stomatal ledges are smooth, and the guard cells are covered with only few wax crystals. Among the resistant ecotypes, C, ESP.100 exhibits dentated stomatal ledges with few epicuticular wax depositions; D, ESP.162 shows dentated ledges with few wax crystals on the guard cells; E, GRC.045 has stomatal ledges with waxy projections occluding the stomatal opening; and F, F11.008 exhibits smoothly dentated ledges with very few small epicuticular wax crystals. (Bars $=1 \mu \mathrm{m}$ ). covering the guard cells and in the height and structure of stomatal ledges (Fig. 1A to F). Even accessions with partly occluded stomata (Fig. 1E) did not exhibit reduced penetration efficiency. Thus, the surface sensing system of the $U$. striatus germ tube permits the recognition of a quite diverse array of stomatal topographies.

Microscopic analysis of infection. Development of rust infections within the leaves of selected Medicago lines was studied by light microscopy. Three days after inoculation, the accessions already differed considerably in the number of haustoria formed per infection site (Fig. 2). In the susceptible cvs. Europe and Jemalong, the number of haustoria was significantly higher than in the resistant lines. Although, in the susceptible cultivars, all haustoria were formed properly, rust development frequently was arrested after formation of haustorial mother cells in DZA.045 (47.3\%), ESP.100 (26.7\%), ESP.162 (50.0\%), and GRC.098 $(34.7 \%)$. If infection was not blocked at this stage, fungal growth was stopped after haustorium formation. In the ecotype F11.008, almost no haustorium was observed even 8 days after inoculation (Fig. 2), and fungal development was stopped at the prehaustorial stage in $94.7 \%$ of the penetration sites.

To characterize the defense reactions of the different accessions, the number of necrotic plant cells per infection site and autofluorescence of cells within infection sites were compared (Figs. 3 and 4). In cv. Europe, no necrotic cells were visible and, in Jemalong, only very few necrotic cells occurred (Fig. 3). In both susceptible cultivars, no autofluorescence was observed around the infection sites. In contrast, the resistant Medicago accessions DZA.045, ESP.100, ESP.162, and GRC.098 exhibited strong autofluorescence after fungal penetration and numerous necrotic cells around the infection sites. The strongest fluorescence was detected in M. truncatula DZA.045 (Fig. 4A1 and A2). Here, primary and a few secondary haustoria were formed and infected cells did not show any visible defense reaction. Only neighboring plant cells turned brown and exhibited strong autofluorescence. Nine days after inoculation, some small uredosori could be observed surrounded by rings of necrotic cells (data not shown). In contrast, in ESP.100, ESP.162, and GRC.098, numerous haustorium-containing necrotic cells with strong cytoplasmic autofluorescence were detected (Fig. 4B1 and B2). At 9 to 10 days after inoculation, very small pinpoint uredosori were

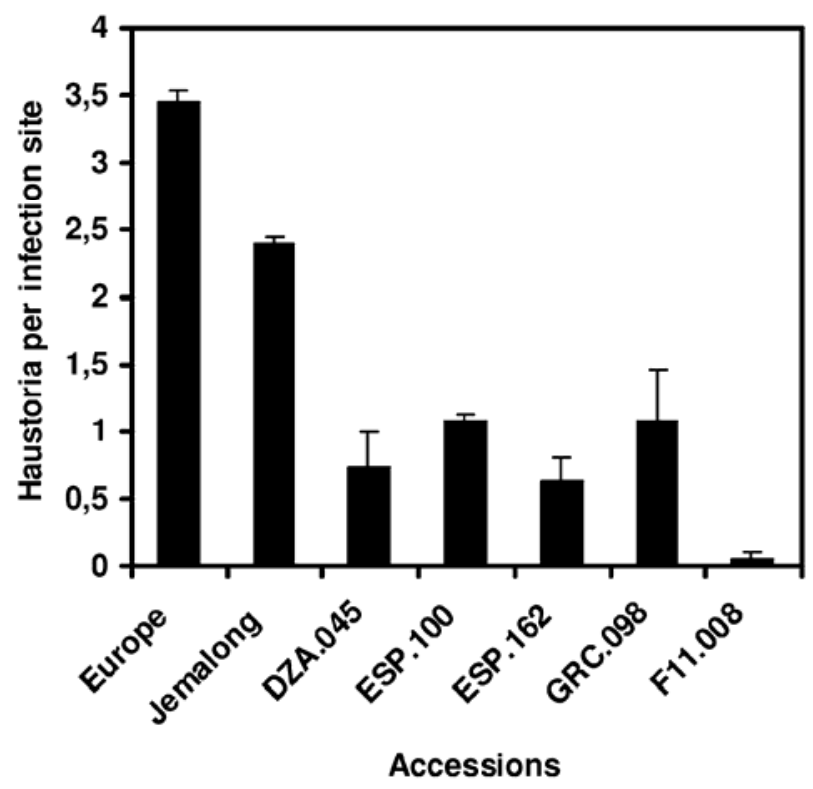

Fig. 2. Efficiency of haustorium formation in different Medicago accessions (3 days after inoculation). Each column indicates the mean of five leaves with a total of 150 infection sites counted per accession. Error bars indicate standard deviation. 
formed, producing only up to 10 uredospores/pustule (data not shown). In contrast to all other cultivars, rust development in ecotype F11.008 stopped completely at the stage of haustorial mother cell differentiation (Fig. 4C2). In this accession, nearly no haustoria and only very few necrotic or fluorescent cells were observed in the vicinity of fungal hypha (Fig. 4C1). Even at 14 days after inoculation, no sporulation was detected (data not shown).

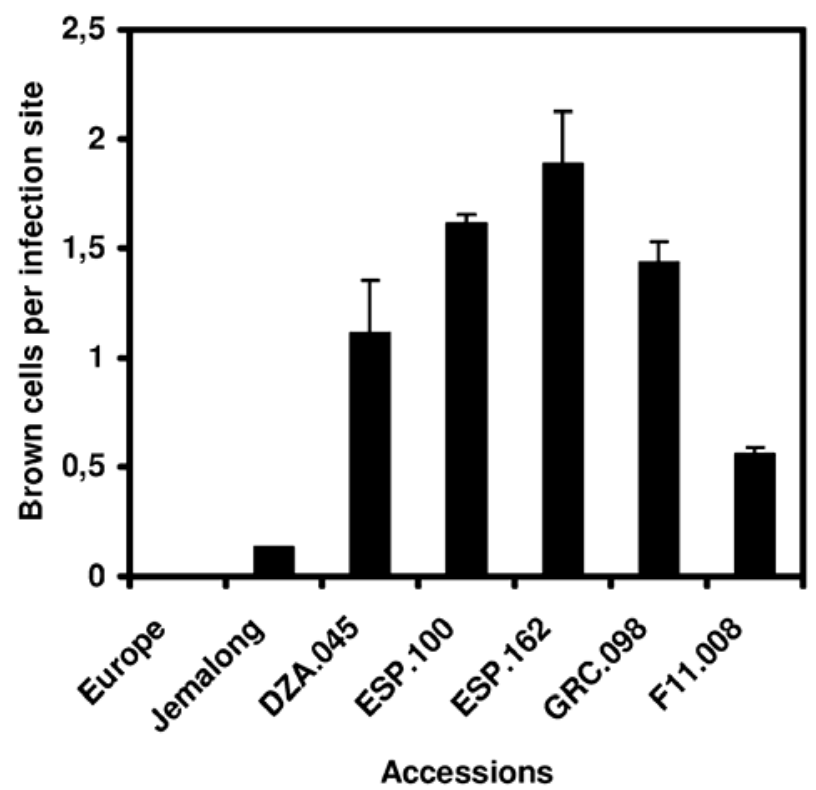

Fig. 3. Number of necrotic cells per infection site (3 days after inoculation). Each column indicates the mean of three leaves with a total of 90 infection sites counted per accession. Error bars indicate standard deviation.

\section{DISCUSSION}

The screening of 113 mainly European M. truncatula accessions inoculated with $U$. striatus isolate KN1 revealed 108 accessions that represent the typical compatibility reaction which results in sporulating pustules. Nevertheless, five Medicago ecotypes showed strong resistance as evidenced by a lack of pronounced pustules.

SEM of leaf surfaces around the stomata of $M$. truncatula accessions revealed major differences both in the arrangement of wax crystals and in the size and shape of guard cell lips. Yet, appressorium formation of $U$. striatus in these accessions did not differ significantly. This is in contrast to results obtained by VazPatto and Niks (20) with Puccinia hordei in different accessions of Hordeum chilense. Their study indicates that failure to form appressoria was due to the presence of a prominent wax layer over the guard cells of the particular Hordeum line.

Studies with artificial substrata showed that optimal appressorium formation of $U$. striatus was induced on a wide range of ridges ranging from 0.1 to $1.2 \mu \mathrm{m}$ in height (E. Kemen and $\mathrm{K}$. Mendgen, unpublished data), indicating a low specificity of topographic sensing compared with other species of rust fungi, such as $U$. appendiculatus and $U$. vignae, which showed an optimal induction of appressoria on ridges in a narrow range from 0.4 to $0.8 \mu \mathrm{m}$ (2). Thus, the ability of $U$. striatus germlings to respond to different surface topographies with efficient appressorium development might be an adaptation that contributed to the wide host range of at least 141 legume species (15).

Successful penetration is followed by the development of a sequence of specialized infection structures within the substomatal cavity and the formation of nutrient absorbing haustoria within the host mesophyll cells (8). Three days after inoculation with $U$. striatus, $M$. sativa cv. Europe and M. truncatula Jemalong showed well-developed colonies of intercellular mycelium with
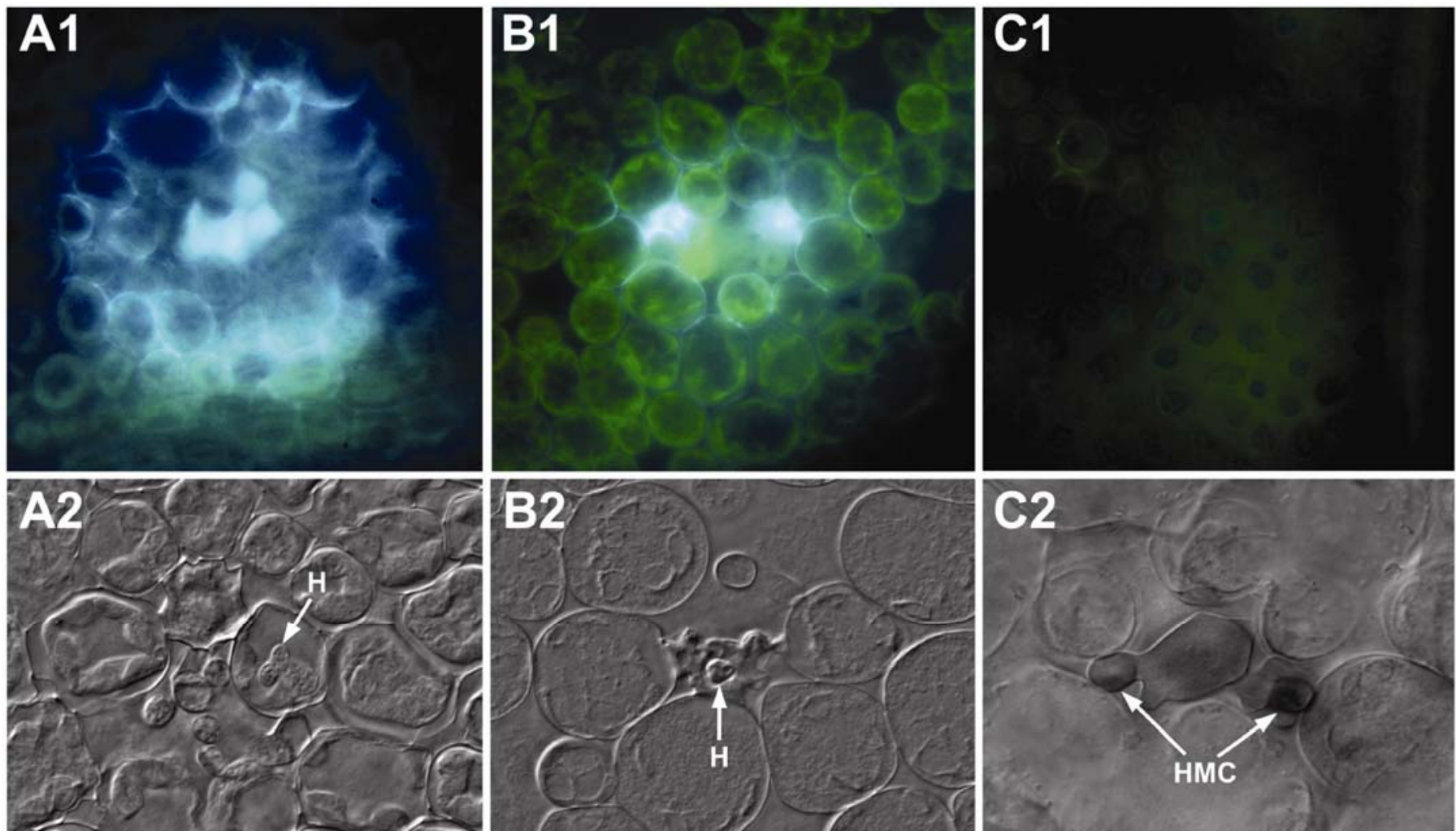

Fig. 4. A1 to C1, Epifluorescence and $\mathbf{A 2}$ to $\mathbf{C 2}$, differential interference contrast images of Uromyces striatus infection sites 3 days after inoculation. A, In DZA.045, intercellular hyphae proliferate and haustoria $(\mathrm{H})$ are differentiated. Surrounding noninfected cells start to collapse within the infected area; later, cells with haustoria necrotize. B, In ESP.100, infected cells collapse, turn brown, and show fluorescence as soon as haustoria develop. C, In F11.008, infection hyphae inflate soon after leaf penetration and differentiate haustorial mother cells (HMC). Only a few haustoria could be found. 
numerous haustoria. However, the number of haustoria per infection site was higher for $M$. sativa (3.4 haustoria) than for M. truncatula Jemalong (2.4 haustoria). The reason might be that $M$. truncatula represents an inferior host compared with $M$. sativa, as has been described (6).

Plant reactions within resistant ecotypes differed clearly. In the ecotypes DZA.045, ESP.100, ESP.162, and GRC.098, accumulation of fluorescing compounds and necrotic cells was observed. DZA.045 showed both fluorescence of cells and an intense yellow-blue autofluorescence of cell walls surrounding the infection site, indicating the deposition of lignin and lignin-like phenolics (5). In addition, abortion of cells not forming any haustoria was observed and haustorium development was severely restricted, leading to very poor sporulation.

The ecotypes ESP.100, ESP.162, and GRC.098 showed brownish cells for resistant accessions of $M$. truncatula as described recently (14), but also strong autofluorescence was detected, both typical characteristics of hypersensitive reactions as previously described by Elmhirst and Heath (4). The reactions were very similar to that described earlier for wheat lines containing the Sr5 gene for resistance against $P$. graminis f. sp. tritici (19).

In contrast to the other resistant lines, the M. truncatula line F11.008 showed prehaustorial resistance. Fungal development stopped immediately after formation of haustorial mother cells without necrosis of cells in contact with the fungus. Thus, it has the characteristics of a non-hypersensitivity resistance (3). Observations of late infection stages (14 days postinoculation) did not reveal further development of the fungus or the production of haustoria. This appears to be a new interaction type which has not been described before in M. truncatula. Similar high levels of resistance have been described for several other plant-rust fungi interactions $(3,11)$. This type of resistance typically is exhibited by nonhost plants (9) and presents a highly effective and durable resistance (18). However, it is suspected that plants exhibiting nonhost resistance within a susceptible species may have been evolved from ancestors that were susceptible (10). Nevertheless, it seems to be based on multiple defense mechanisms, as previously shown by studies of a variety of Arabidopsis mutants inoculated with the nonpathogenic fungus U. vignae (12) as well as of Hordeum vulgare cultivars inoculated with $P$. triticina (13). An example of nonhost resistance has been described showing that the hypersensitive reaction is not always required: an Arabidopsis mutant ( $d n d 1)$ which shows a defect in hypersensitive cell death but retains resistance against an avirulent Pseudomonas syringae strain (22).

The availability of Medicago ecotypes presented in this study opens the possibility for studying the molecular basis of important resistance factors of legumes, especially a strong nonhost-like form of defense.

\section{ACKNOWLEDGMENTS}

We thank J. M. Prosperi for providing the Medicago truncatula seed, $\mathrm{H}$. Hoch for providing the polystyrene replicas, R. Rohringer for critical reading of the manuscript, two anonymous reviewers for their suggestions, and C. Giele and U. Peters for providing excellent technical assistance.

\section{LITERATURE CITED}

1. Adam, L. 1999. Comparison of Erysiphe cichoracearum and E. cruciferarum and a survey of 360 Arabidopsis thaliana accessions for resistance to these two powdery mildew pathogens. Mol. Plant-Microbe Interact. 12:1031-1043.

2. Allen, E. A., Hazen, B. E., Hoch, H. C., Kwon, Y., Leinhos, G. M. E., Staples, R. C., Stumpf, M. A., and Terhune, B. T. 1991. Appressorium formation in response to topographical signals by 27 rust species. Phytopathology 81:323-331.

3. Anker, C. C., and Niks, R. E. 2001. Prehaustorial resistance to the wheat leaf fungus Puccinia triticina, in Triticum monococcum (s.s.). Euphytica 117:209-215.

4. Elmhirst, J. F., and Heath, M. C. 1989. Interactions of the bean rust and cowpea rust fungi with species of the Phaseolus-Vigna plant complex. II. Histological responses to infection in heat-treated and untreated leaves. Can. J. Bot. 67:58-72.

5. Fink, W., Haug, M., Deising, H., and Mendgen, K. 1991. Early defence responses of cowpea (Vigna sinensis L.) induced by non-pathogenic rust fungi. Planta 185:246-254.

6. Gäumann, E. 1959. Die Rostpilze Mitteleuropas. Bücheler \& Co., Bern.

7. Guyot, A. L. 1957. Les Urédinées. Editions Paul Lechevalier, Paris.

8. Hahn, M., and Mendgen, K. 2001. Signal and nutrient exchange at biotrophic plant-fungus interfaces. Curr. Opin. Plant Biol. 4:322-327.

9. Heath, M. C. 1981. Resistance of plants to rust infection. Phytopathology 71:971-974.

10. Heath, M. C. 1997. Evolution of plant resistance and susceptibility to fungal parasites. Pages 257-276 in: The Mycota V Part B. G. C. Carroll and P. Tudzynski, eds. Springer-Verlag, Berlin.

11. Hoogkamp, T. J. H., Chen W.-Q., and Niks, R. E. 1998. Specificity of prehaustorial resistance to Puccinia hordei and to two inappropriate rust fungi in barley. Phytopathology 88:856-861.

12. Mellersh, D. G., and Heath, M. C. 2003. An investigation into the involvement of defense signaling pathways in components of the nonhost resistance of Arabidopsis thaliana to rust fungi also reveals a model system for studying rust fungal compatibility. Mol. Plant-Microbe Interact. 16:398-404.

13. Neu, C., Keller, B., and Feuillet, C. 2003. Cytological and molecular analysis of the Hordeum vulgare-Puccinia triticina nonhost interaction. Mol. Plant-Microbe Interact. 16:626-633.

14. Rubiales, D., and Moral, A. 2004. Prehaustorial resistance against alfalfa rust (Uromyces striatus) in Medicago truncatula. Eur. J. Plant Pathol. 110:239-243.

15. Skinner, D. Z. 1995. Host range expansion of the alfalfa rust pathogen. Plant Dis. 79:456-460.

16. Stakman, E. C., Stewart, D. M., and Loegering, W. Q. 1962. Identification of physiologic races of Puccinia graminis var. tritici. Agric. Res. Serv. E617, U.S. Dep. Agric. Washington, DC.

17. Thoquet, P., Ghérardi, M., Journet, E.-P., Kereszt, A., Ané, J.-M., Prosperi, J.-M., and Huguet, T. 2002. The molecular genetic linkage map of the model legume Medicago truncatula: An essential tool for comparative legume genomics and the isolation of agronomically important genes. BMC Plant Biol. 2:1.

18. Thordal-Christensen, H. 2003. Fresh insights into processes of nonhost resistance. Curr. Opin. Plant Biol. 6:351-357.

19. Tiburzy, R., and Reisener, H. J. 1990. Resistance of wheat to Puccinia graminis f. sp. tritici. Association of the hypersensitive reaction with the cellular accumulation of lignin-like material and callose. Physiol. Mol. Plant Pathol. 36:109-120.

20. Vaz Patto, M. C., and Niks, R. E. 2001. Leaf wax layer may prevent appressorium differentiation but does not influence orientation of the leaf rust fungus Puccinia hordei on Hordeum chilense leaves. Eur. J. Plant Pathol. 107:795-803.

21. Young, N. D., Mudge, J., and Ellis, T. H. N. 2003. Legume genomes: More than peas in a pod. Curr. Opin. Plant Biol. 6:199-204.

22. Yu, I. C., Parker, J., and Bent, A. F. 1998. Gene-for-gene disease resistance without the hypersensitive response in Arabidopsis dndl mutant. Proc. Natl. Acad. Sci. USA 95:7819-7824. 